\title{
TEKNIK PENGELOLAAN SUMBER DAYA ALAM UNTUK KONSERVASI DI AREA PEMUKIMAN
}

\author{
Fabiola B. Saroinsong \& Josephus I. Kalangi \\ Fakultas Pertanian, Universitas Sam Ratulangi \\ fabiolasaroinsong@ymail.com; innokalangi@gmail.com
}

\begin{abstract}
Abstrak
Tindakan praktis pelestarian lingkungan merupakan kebutuhan yang tidak bisa ditunda lagi dan bukan hanya Upaya pemanfaatan sumber daya alam tanpa menimbulkan kerusakan lingkungan perlu dilengkapi dengan pemahaman dan penguasaan teknik pengelolaan yang tepat. Karenanya adalah penting untuk melakukan pembekalan dan pengkayaan ilmu dan teknologi pengelolaan sumber daya alam yang berasas konservasi terhadap masyarakat. Dengan demikian, dalam memanfaatkan sumber daya alam masyarakat melakukan aplikasi praktis untuk konservasi lingkungan. Tujuan kegiatan ini adalah melakukan diseminasi Iptek dalam bentuk penyuluhan tentang teknik pengelolaan sumber daya alam untuk konservasi di area pemukiman dan sekitarnya. Metode pelaksanaan kegiatan yaitu penyuluhan/penyadaran, dengan waktu efektif pelaksanaan kegiatan yaitu enam (6) bulan. Evaluasi kegiatan IbM membawa pada kesimpulan bahwa masyarakat dan pemerintah setempat menyambut baik kegiatan yang dilangsungkan dan memberikan respon positif dengan meminta kelanjutan pelaksanaan kegiatan. Masyarakat memahami beberapa aplikasi praktis teknik pengelolaan sumber daya alam untuk konservasi lingkungan yang memungkinkan untuk diterapkan di lingkungannya sendiri.

Kata Kunci: konservasi, lingkungan, pengelolaan, sumber daya alam.
\end{abstract}

\section{PENDAHULUAN}

Kehidupan manusia tidak bisa dipisahkan dari lingkungannya. Lingkungan adalah segala sesuatu yang ada di sekitar manusia yang mempengaruhi perkembangan kehidupan manusia baik langsung maupun tidak langsung. Dengan peran yang sangat penting ini, maka kerusakan lingkungan hidup yang terjadi merupakan hal yang serius (Manik, 2007; Kardan, 2015).

Berdasarkan faktor penyebabnya, bentuk kerusakan lingkungan hidup dibedakan menjadi 2 jenis, yaitu 1) kerusakan lingkungan hidup akibat peristiwa alam, dan 2) kerusakan lingkungan hidup karena faktor manusia. Manusia sebagai pengelola sumber daya alam berperan besar dalam menentukan kelestarian lingkungan hidup. Seringkali apa yang dilakukan masyarakat tidak diimbangi dengan pemikiran akan masa depan kehidupan generasi berikutnya bahkan juga kurang didasari pertimbangan akan dampak buruk terhadap kualitas hidupnya sendiri (Soerjani, 2009; Sasaoka and Laumonier, 2012; Setyowati, Sunarko, dan Sedyawaati, 2014; Sandifer, SuttonGrier, and Ward, 2015). Padahal, tindakan pemanfaatan sumber daya alam seharusnya berpijak pada tujuan yang berwawasan lingkungan. Pengelolaan sumber daya alam berwawasan lingkungan adalah usaha meningkatkan kualitas manusia secara bertahap dengan memerhatikan faktor lingkungan. 
Upaya pemanfaatan sumber daya alam tanpa menimbulkan kerusakan lingkungan perlu dilengkapi dengan pemahaman dan penguasaan teknik pengelolaan yang tepat. Karenanya adalah penting untuk melakukan pembekalan dan pengkayaan ilmu dan teknologi pengelolaan sumber daya alam yang berasas konservasi terhadap masyarakat. Dengan demikian, dalam memanfaatkan sumber daya alam masyarakat melakukan aplikasi praktis untuk konservasi lingkungan (Monroe, Andrews, and Biedienweg, 2007; Neolaka, A. 2008; Soerjani, 2009; Setyowati, Sunarko, dan Sedyawaati, 2014).

Untuk itu perlu dilakukan pembekalan pemahaman yang benar mengenai pengelolaan sumber daya alam termasuk di dalamnya manfaat dan arti penting konservasi, dan teknik-teknik pengelolaan sumber daya alam yang memungkinkan untuk diterapkan masyarakat. Hal inilah yang mendasari pelaksanaan kegiatan pengabdian ini.

Kegunaan kegiatan ini adalah meningkatkan Ilmu Pengetahuan dan Teknologi (Iptek) masyarakat berkaitan dengan teknik pengelolaan sumberdaya alam untuk konservasi, sehingga dalam memanfaatkan sumberdaya alam mereka melakukan aplikasi praktis untuk konservasi lingkungan. Tujuan kegiatan ini adalah melakukan diseminasi Iptek dalam bentuk penyuluhan tentang teknik pengelolaan sumber daya alam untuk konservasi di area pemukiman di Desa 26
Walian I Kecamatan Tomohon Selatan Kota Tomohon.

\section{METODE PELAKSANAAN}

Mitra Kegiatan IbM ini kelompok masyarakat Kelurahan Walian 1 yang meliputi Kelompok Tani dan PKK dengan pendidikan lulusan SD, SMP, SMA, diploma, dan S1. Lokasi kegiatan pengabdian adalah Kelurahan Walian 1 Kecamatan Tomohon Selatan Kota Tomohon, Sulawesi Utara. Kegiatan didanai DIPA DP2M.

Metode pelaksanaan kegiatan yaitu penyuluhan/penyadaran, dengan waktu efektif pelaksanaan kegiatan yaitu enam (6) bulan. Pelaksanaan pengabdian dilakukan dalam beberapa kegiatan sebagai berikut:

1. Pengumpulan data berupa inventarisasi situasi lokasi pelaksanaan kegiatan, diperoleh dengan cara survey lokasi dan wawancara terhadap mitra, lebih khusus lagi Kepala Sekolah dan guruguru masing-masing sekolah yang dimaksud;

2. Penyusunan program bersama mitra dan komunikasi program, sesuai permasalahan dan kebutuhan mitra;

3. Persiapan bahan penyuluhan;

4. Pelaksanaan kegiatan penyuluhan; dan

5. Pelaporan.

\section{HASIL DAN PEMBAHASAN}

Dalam rangka penyuluhan aplikasi praktis teknik pengelolaan sumber daya alam untuk konservasi lingkungan di area pemukiman dan sekitarnya, maka dilakukan 
survei dan pendekatan melalui tokoh masyarakat, dalam hal ini Lurah dan Kepala Lingkungan. Survei dilakukan untuk mengidentifikasi potensi dan kendala pengelolaan sumber daya alam yang diterapkan masyarakat setempat, kondisi umum masyarakat setempat, dan beberapa aplikasi praktis teknik pengelolaan sumber daya alam dengan tujuan konservasi lingkungan yang bisa diterapkan mereka di area pemukiman dan sekitarnya.

Berdasarkan pengamatan di lapangan, seperti halnya banyak desa lainnya, masih terdapat beberapa permasalahan berkaitan dengan pengelolaan sumber daya alam di area pemukiman Desa Walian I Kecamatan Tomohon Selatan. Di antaranya adalah, preferensi masyarakat berkaitan dengan penutupan tanah dengan perkerasan di halaman rumah untuk menghindari becek dan alasan estetika, termasuk juga pelapisan beton selokan tanpa memperhatikan penurunan kemampuan peresepan ke dalam tanah. Pemantauan secara umum juga menunjukkan bahwa terjadi penyeragaman jenis-jenis tanaman hias, penanaman tanaman-tanaman eksotik dan lain-lain. Pengelolaan sumber daya alam kadang tidak disertai pemahaman mengenai konservasi lingkungan dan tidak disertai perencanaan yang tepat. Tindakan ini tidak disadari sebagai tindakan yang memberi dampak negatif bagi kualitas lingkungan dan nantinya akan mengakibatkan pada ketidakberlanjutannya pemanfaatan optimal sumber daya alam.
Kekeliruan tindakan-tindakan pengelolaan sumber daya alam yang dilakukan masyarakat dapat menyebabkan menurunnya potensi pemanfaatan lingkungan antara lain yang terkait dengan pertanian atau pariwisata dan lain-lain, dan juga menyebabkan pada kerusakan sumber daya alam tersebut. Keseimbangan ekosistem menjadi terganggu, sehingga timbul berbagai masalah yang mempengaruhi kualitas kehidupan masyarakat itu sendiri (Manik, 2007; Monroe, Andrews, and Biedienweg, 2007; Neolaka, A. 2008; Soerjani, 2009; Sasaoka and Laumonier, 2012; Roman, 2014; Setyowati, Sunarko, dan Sedyawaati, 2014; Kardan, 2015).

Sebenarnya masyarakat mempunyai kekuatan besar yang dapat memberikan kontribusi penting dan dampak positif dalam konservasi lingkungan. Yang menjadi permasalahannya adalah banyak dari anggota masyarakat yang tidak memiliki pengetahuan yang cukup mengenai teknik pengelolaan lingkungan untuk optimasi pemanfaatan sekaligus pelestarian lingkungan, selain rendahnya pendidikan konservasi. Slogan, ajakan pemerintah dan pemerhati lingkungan tidak diaplikasikan dalam tindakan praktis karena kekurangtahuan metode yang tepat (Sutrisno, 2004; Widada, Mulyati dan Kobayashi, 2003; Hasbullah, 2008; Muslicha, 2015).

Materi penyuluhan didasarkan analisis pengamatan Tim pelaksana di lapangan, lebih khusus lagi berkaitan 
dengan beberapa permasalahan berkaitan dengan pengelolaan sumberdaya alam di area pemukiman Desa Walian I Kecamatan Tomohon Selatan. Permasalahan yang ditemui misalnya yang berkaitan dengan program penghijauan yang dilakukan. Tentunya penanaman pohon dan kegiatan penghijauan adalah hal yang sangat baik, tetapi akan menimbulkan masalah bila terjadi penyeragaman jenis dan penggunaan jenis yang tidak tepat seperti yang terjadi (Indrawan, Primarck, Suprijatna, 2007; Oran, 2016). Karena kurangnya pengetahuan dan teknik pembibitan yang dikuasai masyarakat, penghijauan yang dilakukan di Desa Walian I terbatas pada 1 atau 2 spesies saja dan bukan merupakan tanaman lokal Tomohon maupun Sulawesi Utara. Selain itu, Trembesi yang sebenarnya lebih cocok untuk tempat yang luas atau terbuka karena mudah patah, pertum-buhannya yang cepat dan akarnya dapat membongkar aspal serta perkerasan, ditanam rapat di sepanjang pinggiran jalan.

Selain itu, materi penyuluhan berisi juga pengelolaan sampah sedemikian sehingga tidak mencemari tanah dan air. Penanganan sampah untuk meningkatkan kualitas lingkungan hidup, menjadi input penting dalam pengusahaan pekarangan dan lahan pertanian, serta pemanfaatan hasil pengolahan kompos untuk bisnis tanaman hias dan pembibitan tanaman penghijauan. Hal lain yang ditemui adalah, preferensi masyarakat berkaitan dengan penutupan tanah dengan perkerasan di 28 halaman rumah untuk menghindari becek dan alasan estetika, termasuk juga pelapisan beton selokan tanpa memperhatikan penurunan kemampuan peresepan ke dalam tanah. Selanjutnya, yang juga menjadi perhatian tim pelaksana adalah masih kurangnya kesadaran dalam pengelolaan sampah misalnya sampah dibuang ke saluran air atau dibakar.

Pengelolaan sumber daya alam kadang tidak disertai pemahaman mengenai konservasi lingkungan dan tidak disertai perencanaan yang tepat. Tindakan ini tidak disadari sebagai tindakan yang memberi dampak bagi kualitas lingkungan dan nantinya akan mengakibatkan pada ketidakberlanjutannya pemanfaatan optimal sumber daya alam atau kerusakan sumber daya alam tersebut.

Potret permasalahan yang terekam selama survey adalah kurangnya pengetahuan dan kemampuan teknis masyarakat terkait dengan pelestarian sumberdaya lahan, air, keragaman hayati, serta cara pembibitan dan pengomposan yang baik (Gambar 1).

Penyuluhan dilaksanakan di area pemukiman, di salah satu rumah penduduk setempat. Hal ini dimaksudkan untuk mendekatkan diri dengan obyek penyuluhan. Dalam pelaksanaan penyuluhan tersebut, nara sumber memberikan penjelasan sesuai dengan permasalahan yang ada dan langsung menghubungkannya dengan contoh-contoh sesuai dengan situasi dan kondisi yang terjadi di lapangan (Gambar 2). 


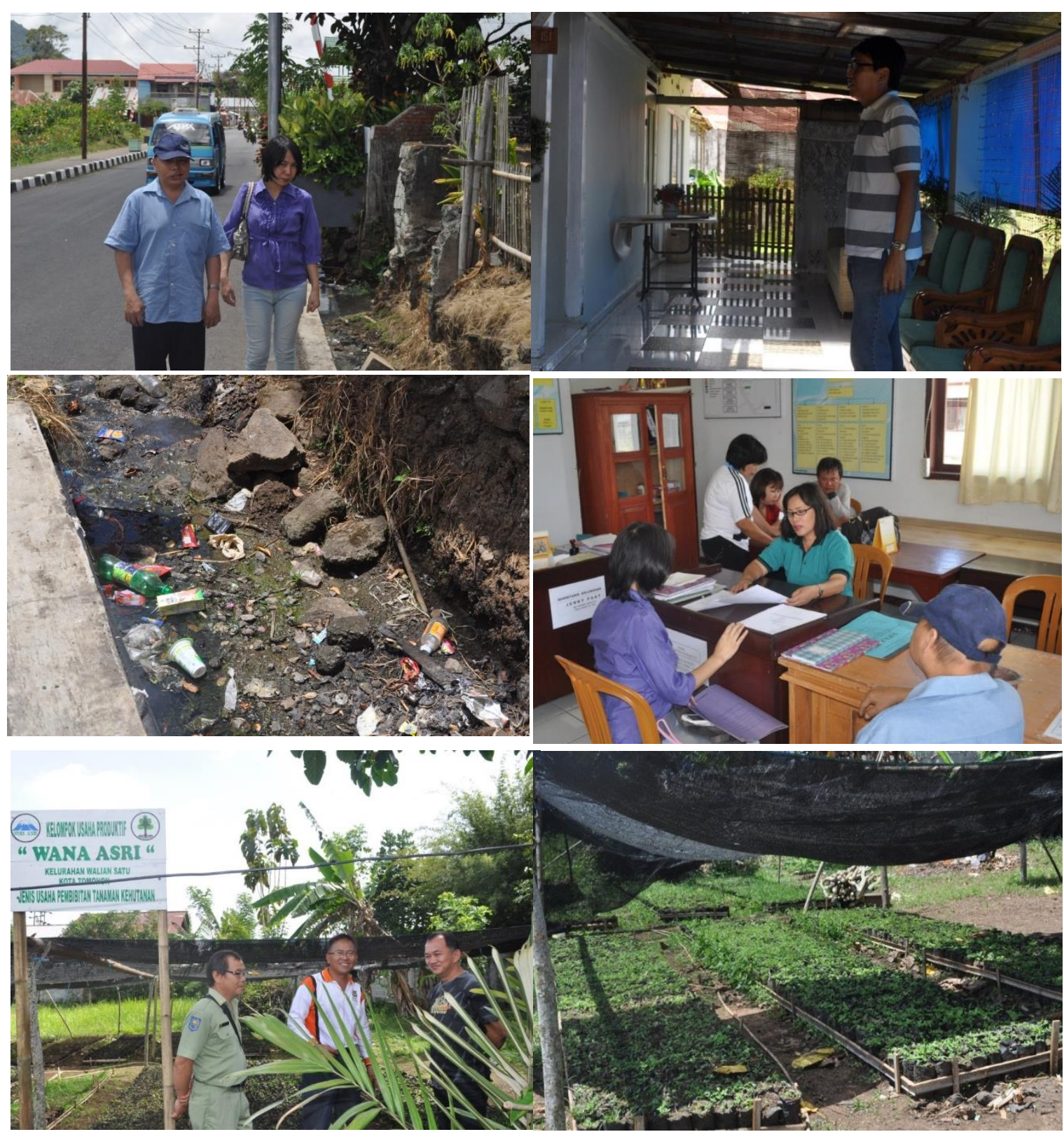

Gambar 1. Survei Lokasi Penelitian dan Diskusi dengan Mitra

Sebenarnya masyarakat mempunyai kekuatan besar yang dapat memberikan kontribusi penting dan dampak positif dalam konservasi lingkungan. Yang menjadi permasalahannya adalah banyak dari anggota masyarakat yang tidak memiliki pengetahuan yang cukup mengenai teknik pengelolaan lingkungan untuk optimasi pemanfaatan sekaligus pelestarian lingkungan. Slogan, ajakan pemerintah dan pemerhati lingkungan tidak diaplikasikan dalam tindakan praktis karena kekurangtahuan metode yang tepat. Karenanya kegiatan transfer Iptek pengelolaan sumber daya alam sebagaimana yang dilakukan dalam kegiatan IbM ini penting untuk melakukan pembekalan pemahaman yang benar mengenai pengelolaan sumber daya alam, kesadaran pentingnya konservasi 
lingkungan, dan teknik-teknik aplikasi diterapkan masyarakat.

praktis yang memungkinkan untuk

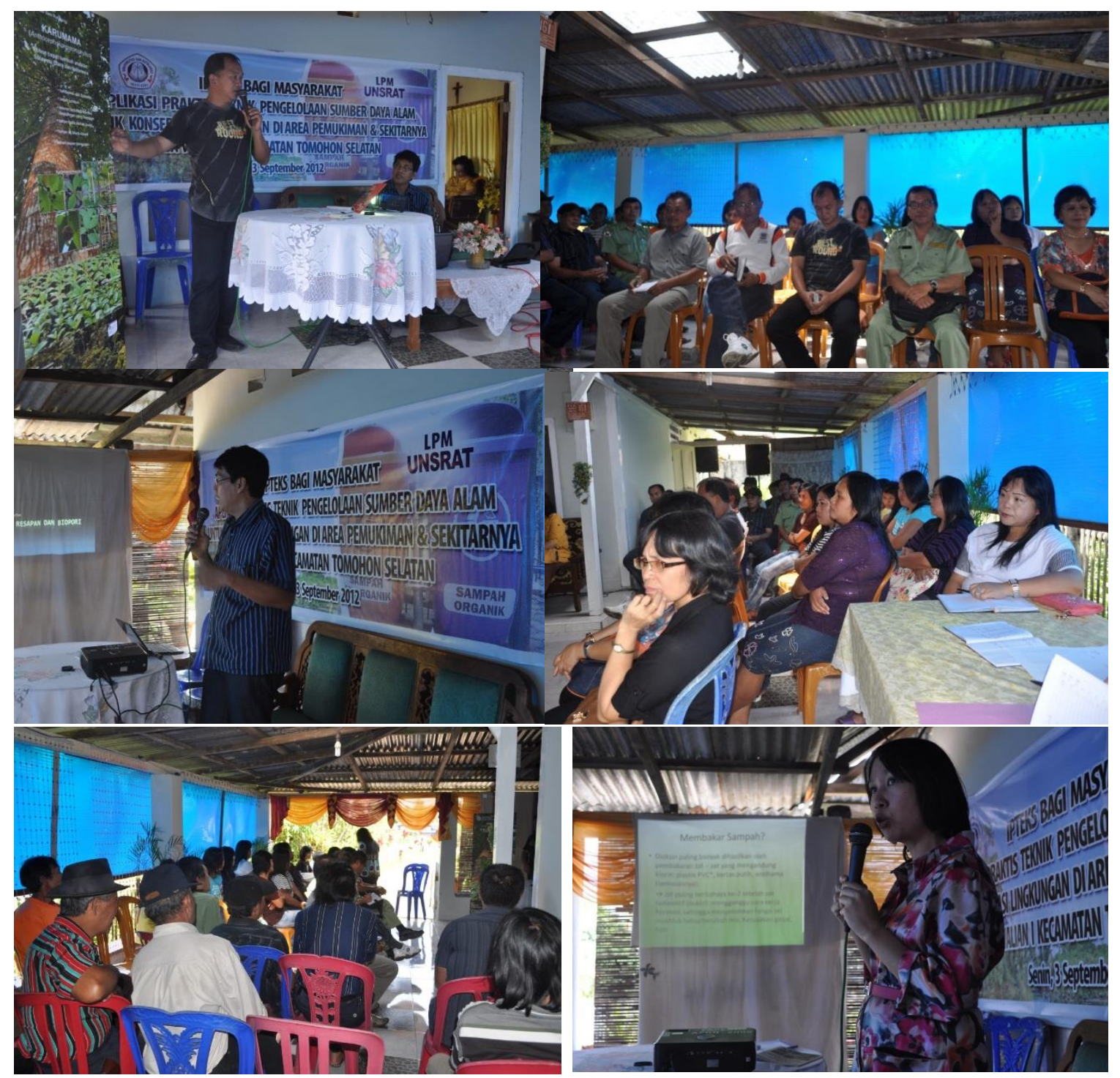

Gambar 2. Penyampaian Materi Penyuluhan

Isi penyuluhan yang dilaksanakan terutama berkaitan dengan pengelolaan sampah, dan kaitannya dengan pembuatan lubang resapan biopori dan pengomposan, serta pengenalan beragam jenis tanaman termasuk jenis tanaman endemik penghasil kayu yaitu Karumama (Jabon).

Materi pengelolaan sampah berisi cara pemilahan sampah rumah tangga (Isrol, 2008; Yogiesti, Hariyani, dan Sutikno,
2010). Pertama, pemisahan antara sampah organik dan anorganik. Untuk sampah sampah kering seperti botol, kaleng, Koran/kertas, plastik sebagian dapat dijual ke pedagang keliling atau penadah. Untuk sampah basah, dapat dikumpulkan dan dimasukkan ke dalam lubang atau kubangan di tanah. Setelah cukup banyak, dapat ditambahkan zat yang mengandung mikroorganisme penghancur (contoh = 
EM4). Dengan demikian sampah basah tersebut akan mengalami proses dan bisa menjadi pupuk kompos. Pupuk kompos bisa digunakan di pekarangan, lahan pertanian, atau juga bisa dijual.
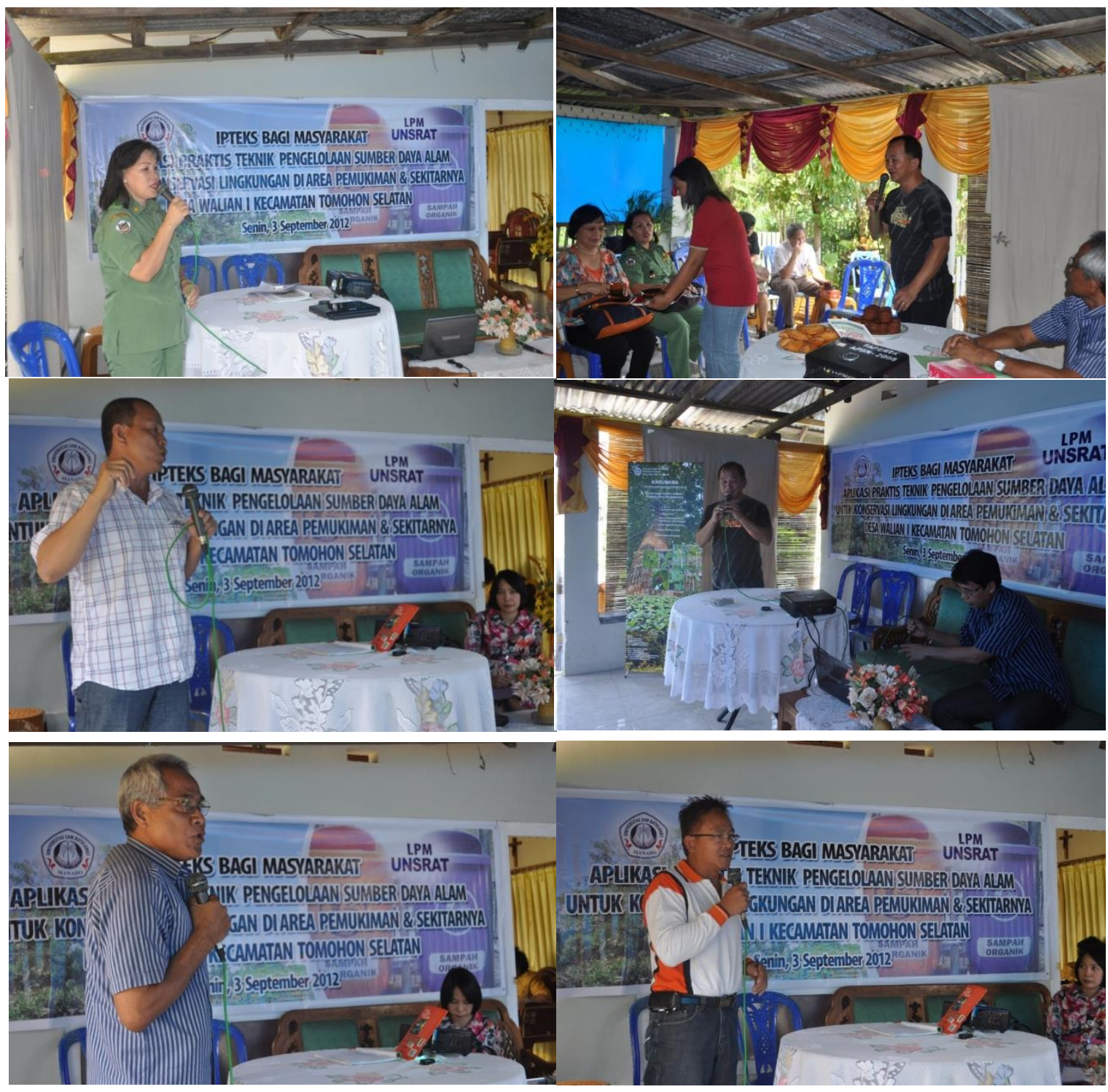

Gambar 3. Diskusi Interaktif

Selanjutnya disampaikan juga teknik pembuatan lubang resapan biopori. Biopori adalah lubang-lubang di dalam tanah yang terbentuk akibat berbagai akitifitas organisma di dalamnya, seperti cacing, perakaran tanaman, rayap dan fauna tanah lainnya. Lubang-lubang yang terbentuk akan terisi udara, dan akan menjadi tempat berlalunya air di dalam tanah. Lubanglubang seperti ini meningkatkan kemampuan dari sebidang tanah untuk meresapkan air, dan memperkecil peluang terjadinya aliran air di permukaan tanah. Atau dengan perkataan lain akan dapat mengurangi bahaya banjir yang mungkin terjadi. Secara alami kondisi seperti itu 
dapat dijumpai pada lantai hutan dimana serasah atau bahan organik terumpuk di bagian permukaan tanah.

Lubang resapan biopori adalah teknologi tepat guna dan ramah lingkungan dengan manfaat (1) meningkatkan daya resapan air, (2) mengubah sampah organik menjadi kompos dan mengurangi emisi gas rumah kaca (CO2 dan metan), dan (3) memanfaatkan peran aktivitas fauna tanah dan akar tanaman, dan mengatasi masalah yang ditimbulkan oleh genangan air seperti penyakit demam berdarah dan malaria.

Pada saat ruang tanya jawab dan diskusi (Gambar 3), masyarakat bertanya atau mengkonfirmasi hal-hal yang belum dimengerti atau berkaitan dengan informasi yang beredar di masyarakat yang tidak jelas kebenarannya. Sebagian masyarakat didukung aparat pemerintah desa dan penyuluh kehutanan setempat mengajukan permintaan yang sama yaitu agar kegiatan serupa dilaksanakan kembali dengan topik pengelolaan sumber daya alam secara khusus kegiatan pelatihan cara membuat pembibitan tanaman-tanaman kayu khususnya jenis lokal, dan cara pembuatan kompos sederhana yang bisa dilakukan secara mandiri oleh mereka. Hal ini tentunya ditanggapi positif oleh Tim IbM dan merencanakan untuk melaksanakan kegiatan pengabdian lanjutan.

\section{KESIMPULAN DAN SARAN}

Evaluasi kegiatan IbM membawa pada kesimpulan bahwa masyarakat dan pemerintah setempat menyambut baik kegiatan yang dilangsungkan dan memberikan respon positif dengan meminta kelanjutan pelaksanaan kegiatan. Dengan penyuluhan, masyarakat mengerti mengenai potensi dan masalah pengelolaan sumber daya alam di area pemukiman dan sekitarnya. Masyarakat memahami dampak pengelolaan sumber daya alam di area pemukiman yang berwawasan lingkungan dan yang tidak. Masyarakat memahami beberapa aplikasi praktis teknik pengelolaan sumber daya alam untuk konservasi lingkungan yang memungkinkan untuk diterapkan di lingkungannya sendiri.

\section{KEPUSTAKAAN}

Ady, C. J. 2007. Conservation Education and Outreach Techniques: An Indispersable Guide for Creating Effective Conservation Education Programs. Ecology Vol. 88(6): 16071618.

Fadhilah, A., Sugianto, A., Firmandhani, S. W., Murtini, T. W., Pandelaki, E. E. 2011. Kajian Pengelolaan Sampah Kampus Jurusan Arsitektur Fakultas Teknik Universitas Diponegoro. Modul 11(2): 62-71.

Hasbullah, H. 2008. Pendidikan Konservasi untuk Orang Dewasa. Tropika 13.

Indrawan, M., Primarck, R., Suprijatna, J. 2007. Biologi Konservasi. Yayasan Obor Indonesia. Jakarta.

Isrol, 2008. Pengomposan Limbah Padat Organik. Balai Penelitian Bioteknologi Perkebunan Indonesia. Bogor.

Kardan, 0. 2015. Neighborhood Greenspace and Health in a Large Urban Center. International Journal of Environmental Health Research 15: 319-337. 
Manik, K. E. S. 2007. Pengelolaan Lingkungan Hidup. Penerbit Djambatan, Jakarta.

Monroe, M. C., Andrews, E., and Biedienweg, K. 2007. A framework for Environmental Education Strategies. Applied Environmental Education and Communication 6: 205-216.

Muslicha, A. 2015. Metode Pengajaran dalam Pendidikan Lingkungan Hidup pada Siswa Sekolah Dasar (Studi pada Sekolah Adwiyata di DKI Jakarta). Jurnal PendidikanVol. 16 No. 2 September 2015 110-126.

Neolaka, A. 2008. Kesadaran Lingkungan. PT Rinika Cipta, Jakarta.

Oran S A. 2016. Plant Diversity of Al-Balqa Governorate, Jordan. International Journal of Biodiversity and Conservation Vol. 8(5): 93-104.

Roman, L. A. 2014. How Many Trees are Enough? Tree Death and the Urban Carbon. Scenario 4(2): 14-20.

Sandifer, P. A., Sutton-Grier A E, Ward B P. 2015. Exploring Connections among Nature, Biodiversity, Ecosystem Services, and Human Health and Wellbeing: Opportunities to Enhance Health and Biodiversity Conservation. Ecosystem Services 12:1-15.
Sasaoka, M., and Y. Laumonier. 2012. Suitability of local resource management practices based on supernatural enforcement mechanisms in the local socialcultural context. Ecology and Society 17(4): 6.

Soerjani, M. 2009; Sasaoka, M., and Y. Laumonier. 2012; Sandifer, P. A., Sutton-Grier A E, Ward B P. 2015.

Setyowati, D. L, Sunarko, R, Sedyawaati S M R. 2014. Pendidikan Lingkungan Hidup. Universitas Negeri Semarang. 82pp.

Soerjani, M. 2009. Pendidikan Lingkungan, Sebagai Dasar Kearifan Sikap Bagi Kelangsungan Kehidupan Menuju Pembangunan Berkelanjutan. Yayasan Institut Pendidikan dan Pengembangan Lingkungan. Jakarta

Surjandari, I., Hidayatno, A., Supriatna, A. 2009. Model Dinamis Pengelolaan Sampah untuk Mengurangi Beban Penumpukan. Jurnal Teknik Industri Vol. 11(2): 134-147.

Yogiesti, V., Hariyani, S., Sutikno, F. R. 2010. Pengelolaan Sampah Terpadu Berbasis Masyarakat Kota Kediri. Jurnal Tata Kota dan Daerah Vol. 2(2) 2: 95-102. 
Jurnal ABDIMAS, Vol. 9, No. 1, Juni 2016 ISSN: 1979-0953 